\title{
Modul Pembelajaran Analisis Karakter Morfologi, Anatomi, dan Agronomi Kedelai Berbasis PjBL untuk Siswa SMK Pertanian
}

\author{
Made Dedi Agustinus ${ }^{1}$, Siti Zubaidah ${ }^{1}$, Heru Kuswantoro ${ }^{1}$ \\ ${ }^{1}$ Pendidikan Biologi-Universitas Negeri Malang
}

\begin{tabular}{l}
\hline INFO ARTIKEL \\
\hline Riwayat Artikel: \\
Diterima: $17-05-2019$ \\
Disetujui: $20-11-2019$ \\
\hline
\end{tabular}

Kata kunci:

learning module;

soybean;

vocational student;

modul pembelajaran:

kedelai;

siswa SMK

\section{Alamat Korespondensi:}

\section{ABSTRAK}

Abstract: The purpose of this research is to examine the feasibility learning module of analyzes the morphological, anatomical and agronomical characteristics of soybeans based on PjBL for students of Vocational High School/SMK PP Negeri Kupang related to analysis of potential ratios and heterosis of F1 soybeans as a result of crossing Burangrang varieties. The development model uses ADDIE which consists of five stages, that is analyze, design, develop, implement, evaluate by Branch. Modules developed were assessed for their feasibility by validators of material experts, resource experts and practitioners in school. The results of the study indicate that the modules developed are categorized as very valid and feasible for use in the learning process.

\begin{abstract}
Abstrak: Tujuan penelitian ini adalah menguji kelayakan modul pembelajaran analisis karakter morfologi, anatomi, dan morfologi kedelai berbasis $P j B L$ untuk siswa SMK PP Negeri Kupang berdasarkan penelitian analisis nisbah potensi dan heterosis F1 kedelai hasil persilangan varietas Burangrang. Model pengembangan menggunakan ADDIE yang terdiri dari lima tahapan yaitu analyze, design, develop, implement, evaluate oleh Branch. Modul yang dikembangkan dinilai kelayakannya oleh validator ahli materi, ahli media dan praktisi lapangan. Hasil penelitian menunjukkan bahwa modul yang dikembangkan berkategori sangat valid dan layak digunakan dalam proses pembelajaran.
\end{abstract}

Orientasi pendidikan di SMK bertujuan menghasilkan lulusan yang memiliki pengetahuan dan keterampilan yang dibutuhkan dalam dunia kerja (Hanafi, 2012). Tujuan lain membentuk lulusan yang mampu menciptakan lapangan kerja (Samsudi, 2014). Pencapaian tujuan pendidikan SMK dilakukan melalui pengembangan aspek pengetahuan, keterampilan dan sikap secara terpadu dan utuh dalam proses pembelajaran (Windriyas, 2014). Pembelajaran di SMK, meliputi tiga kegiatan yang saling berhubungan dan menunjang, yaitu kegiatan pembelajaran tatap muka di kelas, kegiatan praktik di sekolah dan praktik lapangan ke luar sekolah (Kemendikbud, 2017b).

Tantangan yang dihadapi dalam dunia SMK berhubungan dengan kesesuaian antara pengetahuan dan keterampilan yang diajarkan dengan kebutuhan dunia kerja dan industri (Hanafi, 2012). Siswa di abad 21 dituntut menjadi manusia yang mampu mengatasi permasalahan kompleks melalui pengembangan berbagai keterampilan di sekolah (Zubaidah, 2018). Berbagai variasi model pembelajaran praktik dilaporkan efektif meningkatkan kualitas pembelajaran di SMK. Pembelajaran dengan model pembelajaran praktik berbasis kompetensi berorientasi produksi efektif meningkatkan aspek kognitif, afektif, keterampilan dan kualitas produk yang dihasilkan (Mursid, 2013). Model pembelajaran praktik berpasangan mampu meningkatkan kualitas pembelajaran dan hasil belajar (Suhartono \& Soeharto, 2014). Penguasaan model pembelajaran praktik untuk meningkatkan hasil pembelajaran masih harus dilengkapi dengan penggunaan media pembelajaran (Sutrisno \& Siswanto, 2016).

Analisis kebutuhan yang dilakukan melalui wawancara dengan guru dan pengisian angket oleh siswa di SMK Pertanian Pembangunan Negeri Kupang terungkap bahwa pengembangan modul pembelajaran agribisnis tanaman pangan, terutama materi ruang lingkup dan analisis karakteristik tanaman pangan penting dilakukan. Ruang lingkup materi agribisnis tanaman pangan meliputi berbagai tanaman pangan dengan karakteristik yang berbeda yang memerlukan waktu yang lama bila harus dipelajari satu per satu di kelas. Bahan ajar yang selama ini digunakan di sekolah adalah buku paket dan modul yang dikembangkan sendiri oleh guru. Kekurangan kedua bahan ajar tersebut adalah bahasan materi yang lebih banyak mengarah pada padi dan jagung, sehingga memerlukan pengembangan bahan ajar lain yang membahas tanaman pangan lain seperti kedelai. Kegiatan praktik yang dilakukan di sekolah belum memanfaatkan kedelai secara intensif, sehingga pengetahuan dan keterampilan yang dimiliki siswa, utamanya terkait pengamatan dan analisis karakteristik kedelai masih kurang. 
Peningkatan pengetahuan dan keterampilan siswa SMK pertanian terkait materi analisis karakteristik kedelai sangat penting dilakukan. Nilai ekonomi kedelai terbesar setelah padi dan jagung (Tahlim \& Swastika, 2013). Total produksi kedelai nasional tahun 2016 diperkirakan 887.540 ton, kebutuhan konsumsi kedelai sekitar 2,2 juta ton setahun sehingga pemerintah masih impor kedelai sekitar 1,77 juta ton untuk mencukupi kebutuhan (Pusdatin, 2016). Faktor penyebab rendahnya produksi kedelai diantaranya produktivitas rendah (Apri \& Marwoto, 2011) dan serangan penyakit yang menurunkan hasil seperti Cowpea Mild Mottle Virus (CpMMV) (Zubaidah \& Kuswantoro, 2017). Salah satu solusi mengatasi adalah penyediaan varietas unggul tahan penyakit melalui pemuliaan kedelai. Fungsi pemuliaan kedelai, khususnya yang dilakukan secara konvensional adalah membentuk keragaman genetik dan memilih genotipe unggul yang diharapkan (Sa'diyah, Akin, Putri, Jamil, \& Barmawi, 2017). Pemilihan genotipe unggul dilakukan dengan mempertimbangkan karakter morfologi, anatomi, dan agronomi sebagai kriteria. Pemahaman siswa terkait analisis karakteristik kedelai sangat penting untuk mendukung program pemuliaan dan peningkatan produktivitas kedelai.

Pengembangan bahan ajar berbasis hasil penelitian kedelai sudah pernah dikembangkan pada berbagai jenjang pendidikan. Pengembangan bahan ajar SMK berbasis penelitian anatomi daun kedelai (Wijaya, Zubaidah, \& Kuswantoro, 2016) modul budidaya kedelai di SMK (Faot, Zubaidah, \& Kuswantoro, 2016; Nurrohman, Zubaidah, \& Kuswantoro, 2012) bahan ajar bersumber pengamatan morfologi galur kedelai tahan CpMMV (Setiawan, Zubaidah, \& Kuswantoro, 2016) bahan ajar yang mengkaji vektor CpMMV pada kedelai (Paulina Dewi, Rohman, \& Zubaidah, 2016) perangkat pembelajaran berbasis penelitian giberelin terhadap kedelai (Wardhani, Zubaidah, \& Kuswantoro, 2017) LKS PjBL hasil penelitian pemupukan fosfat (Safitri, Zubaidah, \& Kuswantoro, 2018). Berbagai bahan ajar yang telah dikembangkan belum ada yang spesifik membahas analisis karakteristik kedelai yang berhubungan dengan pemuliaan melalui persilangan.

Berdasarkan uraian tersebut, pengembangan modul dengan materi pengukuran dan analisis karakter morfologi, anatomi, dan agronomi hasil persilangan kedelai sangat dibutuhkan. Modul dipilih karena memfasilitasi siswa belajar lebih mandiri tanpa terlalu tergantung dengan kehadiran guru. Keunggulan modul yang lain dapat digunakan dalam pembelajaran di kelas dan luar kelas (praktik mandiri) sehingga dapat mengatasi keterbatasan jam pembelajaran. Sistematika modul yang memadukan antara materi, lembar kerja, dan evaluasi memudahkan siswa mengorganisasi pembelajaran secara tuntas dengan hasil yang terukur (Depdiknas, 2008). Berbagai penelitian menunjukkan bahwa modul dapat meningkatkan kemandirian dan kognitif (Swandhana, 2016), keterampilan, afektif dan keaktifan di kelas (Aisyah, 2011), keterampilan proses sains bila dipadukan dengan model pembelajaran inkuiri dan project based learning (PjBL) (Akhiruddin, Susilo, \& Ibrohim, 2016).

Modul dikembangkan berdasarkan model $P j B L$ untuk mengakomodasi pembelajaran SMK yang dominan kegiatan praktik dibanding pembelajaran teori di kelas. Model PjBL memberikan kesempatan kepada siswa untuk mengembangkan kreativitas, pemecahan masalah nyata dan interaksi melalui pengerjaan suatu proyek (Division, 2006). Kegiatan belajar pada modul yang dikembangkan meliputi tiga materi yaitu analisis karakter morfologi, anatomi, dan agronomi kedelai. Pencapaian tujuan pembelajaran di setiap kegiatan belajar dilakukan disesuaikan dengan sintaks model pembelajaran PjBL (Baker, Trygg, Otto, Tudor, \& Ferguson, 2011).

\section{METODE}

Modul pembelajaran berbasis PjBL dikembangkan dengan model ADDIE (Branch, 2009). Tahapan analyze dilakukan dengan identifikasi permasalahan pembelajaran melalui wawancara guru dan pengisian angket untuk analisis kebutuhan. Berdasarkan analisis kebutuhan ditentukan jenis bahan ajar yang akan dikembangkan. Analisis berikutnya adalah menentukan karakteristik bahan ajar yang akan dikembangkan, yaitu berupa modul pembelajaran berbasis $P j B L$ yang akan digunakan di SMK Pertanian. Tahap design dilakukan penyusunan konten pokok modul sesuai sistematika modul (Depdiknas, 2008). Pada tahap design juga disusun berbagai instrumen pengujian validitas dan uji coba untuk penilaian modul. Tahap develop dilakukan dengan membuat dan menghasilkan modul sesuai dengan rancangan serta dihasilkan berbagai instrumen validasi yang siap digunakan. Pada tahap develop dilakukan uji validasi, uji coba pendahuluan, dan uji coba lapangan terhadap modul yang dikembangkan.

Penentuan validator didasarkan kualifikasi dan latar belakang keilmuan yang dimiliki. Validator ahli materi memiliki bidang keilmuan struktur perkembangan tumbuhan, validator ahli modul memiliki bidang keilmuan dalam menyusun media dan bahan ajar. Validator yang merupakan praktisi lapangan adalah guru mata pelajaran agribisnis tanaman pangan. Modul yang sudah melewati serangkaian uji validasi dan dinyatakan valid, diuji kepraktisan secara bertahap. Diawali dengan uji perseorangan, uji kelompok kecil, dan uji coba lapangan.

Jenis data dalam penelitian ini adalah data kualitatif dan kuantitatif. Data kualitatif meliputi semua saran dan kritik dari validator dan siswa yang dituliskan pada angket. Data kuantitatif meliputi skor perhitungan angket menggunakan skala Likert yang diberikan kepada validator dan ahli pada saat validasi dan uji kepraktisan. Data kualitatif dianalisis secara kualitatif dan dijadikan acuan melakukan perbaikan. Data kuantitatif dianalisis secara deskriptif dalam bentuk persentase dengan menggunakan rumus sebagai berikut.

$$
\text { Persentase validitas modul }=\frac{\Sigma X}{\Sigma X i} \times 100 \%
$$

Keterangan

$\Sigma \mathrm{x} \quad=$ jumlah skor keseluruhan jawaban per butir

¿xi $=$ jumlah skor maksimal per butir 
Pengambilan keputusan validitas modul yang dikembangkan berdasarkan persentase validitas yang dikategorikan yaitu, rentang 85-100\% dengan kategori sangat valid dengan atau tanpa revisi, 70-85\% dengan kategori cukup valid dengan revisi, 60 - 74\% dengan kategori kurang valid dan kurang direkomendasikan digunakan, 40—59\% dengan kategori tidak valid dan tidak boleh digunakan (Akbar, 2013).

\section{HASIL}

Modul yang dikembangkan terdiri dari bagian utama. Bagian awal terdapat halaman sampul dan petunjuk penggunaan modul. Bagian inti merupakan kegiatan belajar sesuai sintaks $P J B L$ dan dilengkapi format evaluasi mandiri. Bagian penutup berisi glosarium. Berikut tiga bagian dari modul yang dikembangkan (Gambar 1-3).

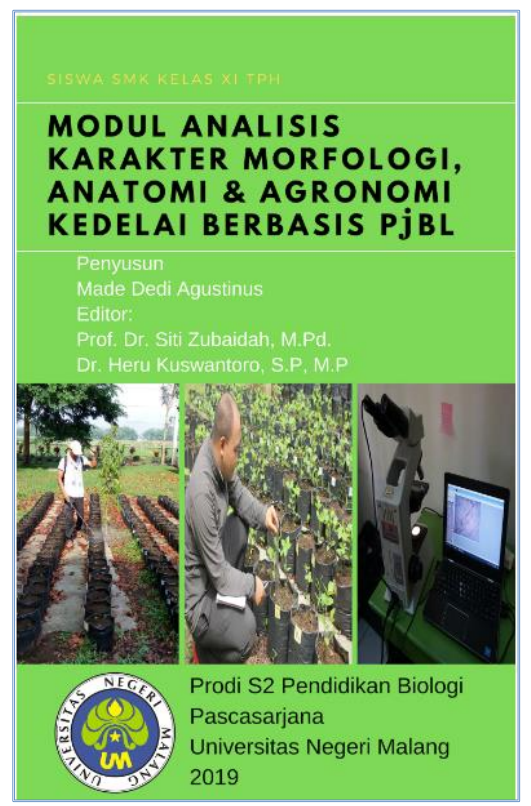

Gambar 1. Sampul Modul

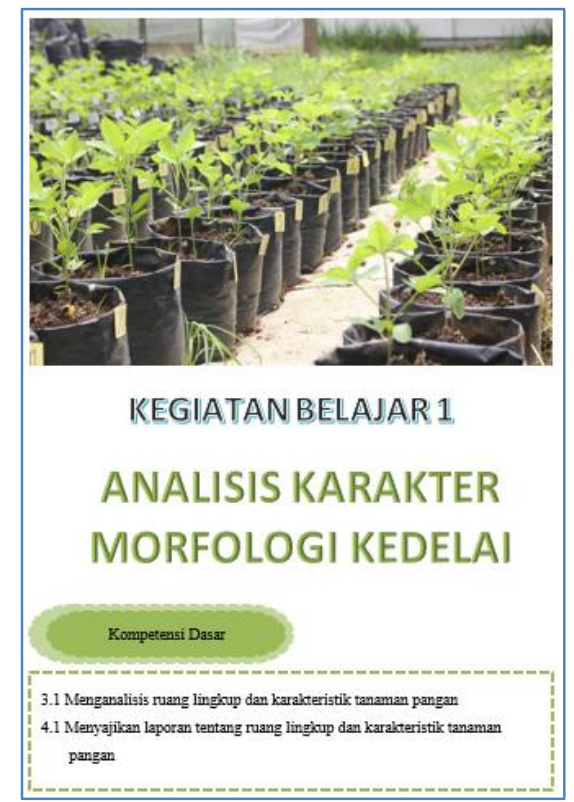

Gambar 2. Kegiatan Belajar Modul

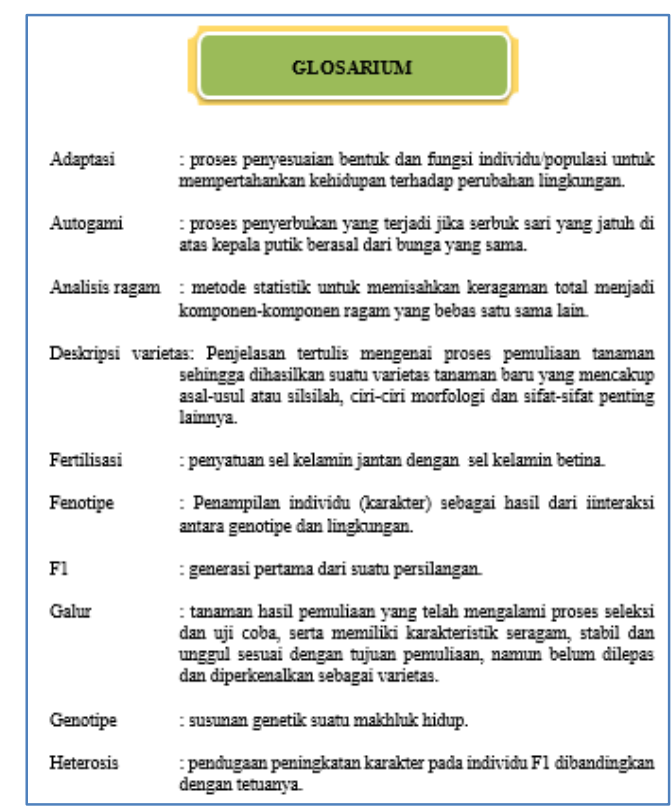

Gambar 3. Glosarium Modul

Modul yang dikembangkan memiliki tiga kegiatan belajar. Kegiatan belajar pertama materi analisis karakter morfologi kedelai, kegiatan belajar kedua materi analisis karakter anatomi kedelai dan kegiatan belajar ketiga materi analisis karakter agronomi kedelai. Kegiatan belajar diawali dengan indikator dan tujuan pembelajaran yang ingin dicapai. Proses pembelajaran dengan modul dilakukan sesuai sintaks model pembelajaran $\mathrm{PjBL}$ yang terdiri dari (1) mengawali dengan pertanyaan mendasar, (2) mendesain perencanaan proyek, (3) menyusun jadwal pelaksanaan proyek, (4) memantau siswa dan kemajuan proyek, (5) menilai hasil, dan (6) mengevaluasi pengalaman (Division, 2006). Berikut tampilan sintaks model PjBL (Gambar 4—9).

Hasil tahap develop berupa modul yang telah direvisi berdasarkan proses validasi oleh ahli materi, ahli modul dan praktisi lapangan. Para ahli yang melakukan validasi memberikan penilaian, komentar, dan saran perbaikan pada angket validasi terhadap modul yang dikembangkan. Berikut hasil validasi secara lengkap terhadap modul yang dikembangkan.

\section{Validasi Oleh Ahli Materi}

Validasi oleh ahli materi meliputi tujuh aspek, yaitu kesesuaian materi dengan KD, keakuratan materi, kedalaman materi, kekontekstualan materi, kemutakhiran materi, mendorong keingintahuan, dan penyajian materi. Ringkasan hasil analisis persentase validasi modul oleh ahli materi terdapat pada tabel 1.

Tabel 1. Hasil Analisis Validasi Modul oleh Ahli Materi

\begin{tabular}{clcccc}
\hline No & \multicolumn{1}{c}{ Aspek } & Skor/Skor Maks & Persentase & Kategori & Keputusan Uji \\
\hline 1 & Kesesuaian materi dengan KD & $12 / 12$ & $100 \%$ & Sangat valid & Sedikit revisi \\
2 & Keakuratan materi & $40 / 44$ & $90,90 \%$ & Sangat valid & Sedikit revisi \\
3 & Kedalaman materi & $8 / 8$ & $100 \%$ & Sangat valid & Sedikit revisi \\
4 & Kekontekstualan materi & $11 / 12$ & $91,66 \%$ & Sangat valid & Sedikit revisi \\
5 & Kemutakhiran materi & $11 / 12$ & $91,66 \%$ & Sangat valid & Sedikit revisi \\
6 & Mendorong keingintahuan & $12 / 12$ & $100 \%$ & Sangat valid & Sedikit revisi \\
7 & Penyajian materi & $18 / 20$ & $90 \%$ & Sangat valid & Sedikit revisi \\
\hline & Rerata total & & $\mathbf{9 4 , 8 8 \%}$ & Sangat valid & Sedikit revisi \\
\hline
\end{tabular}




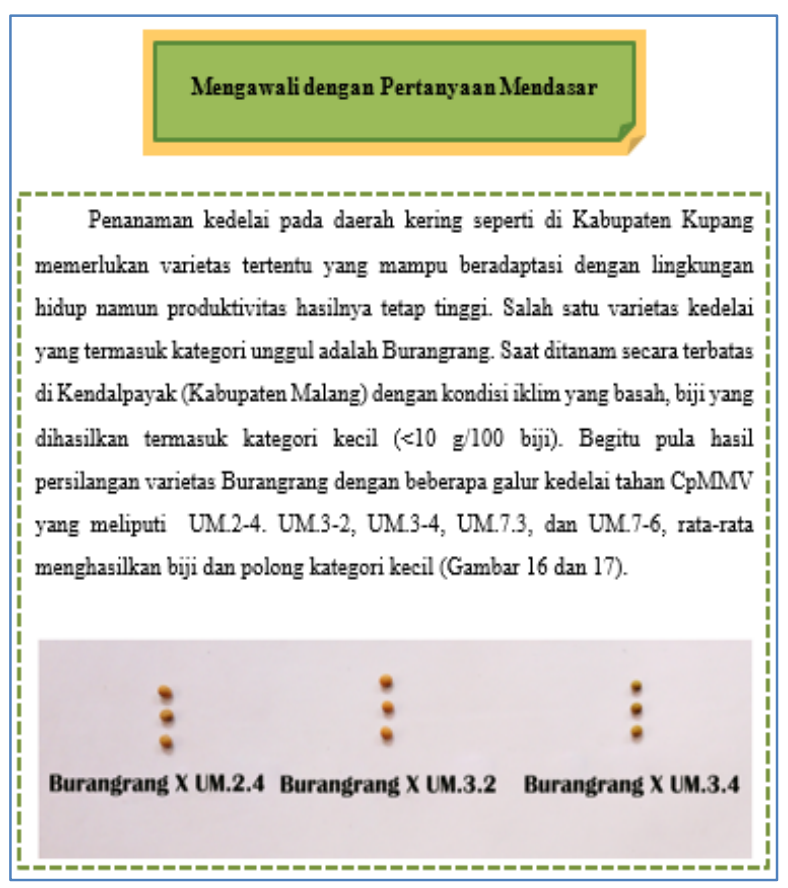

Gambar 4. Sintaks mengawali dengan Pertanyaan

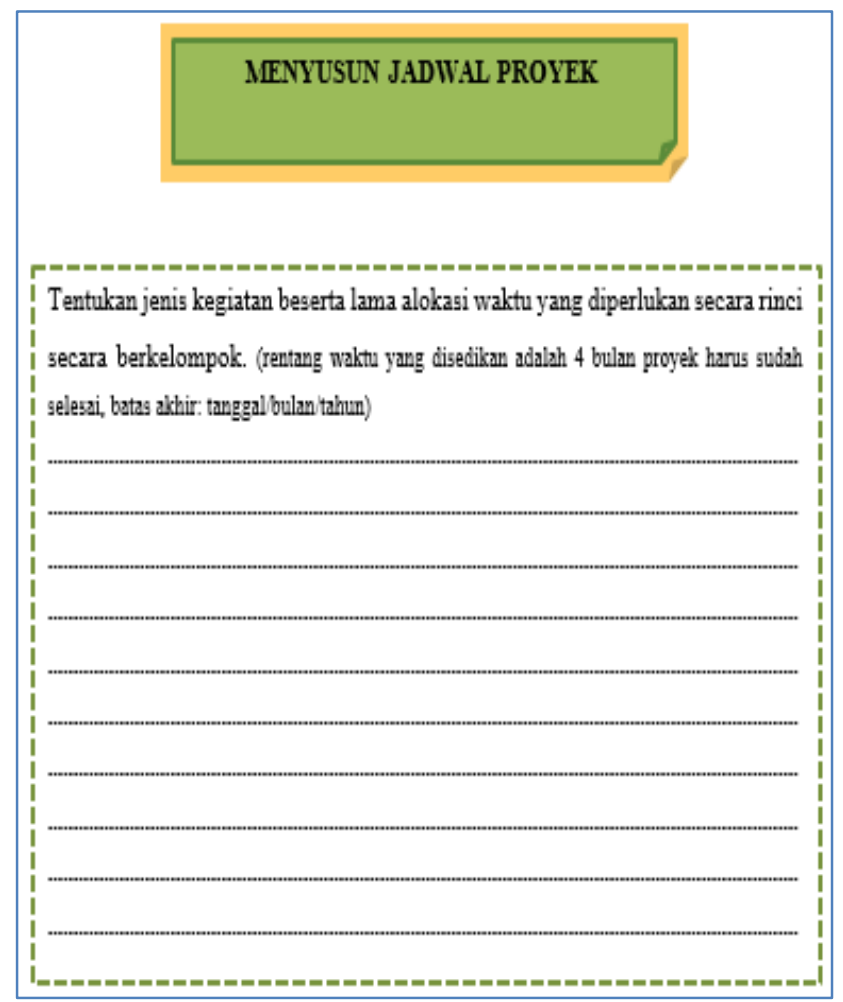

Gambar 6. Sintaks Menyusun Jadwal Proyek

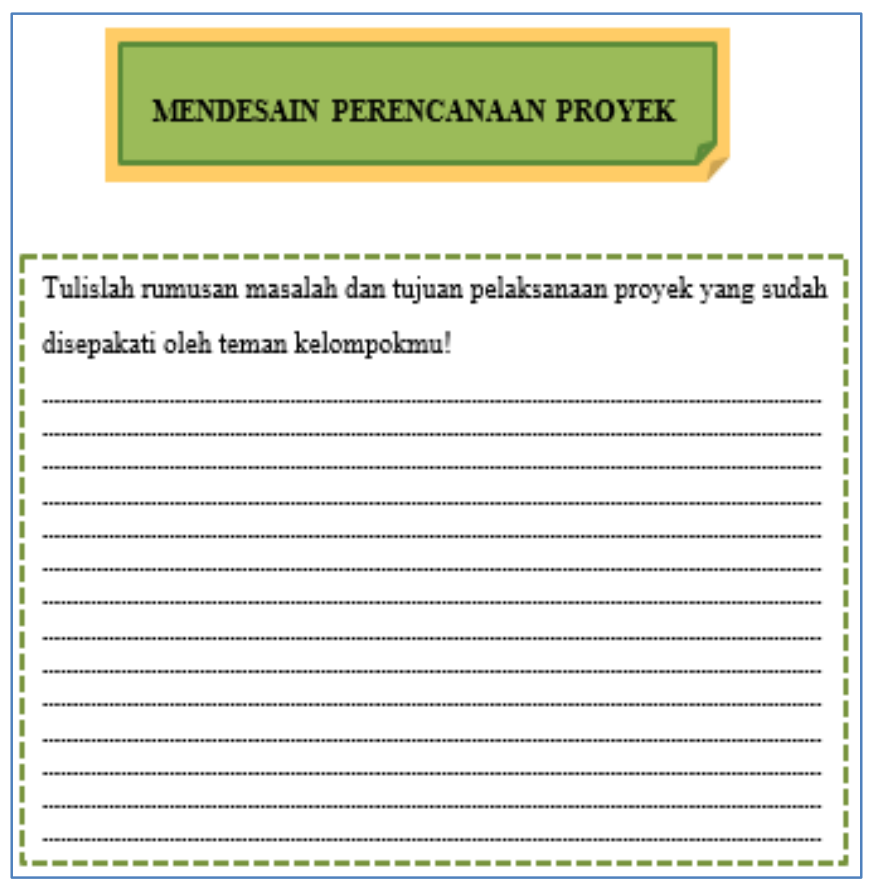

Gambar 5. Sintaks Mendesain Perencanaan Proyek

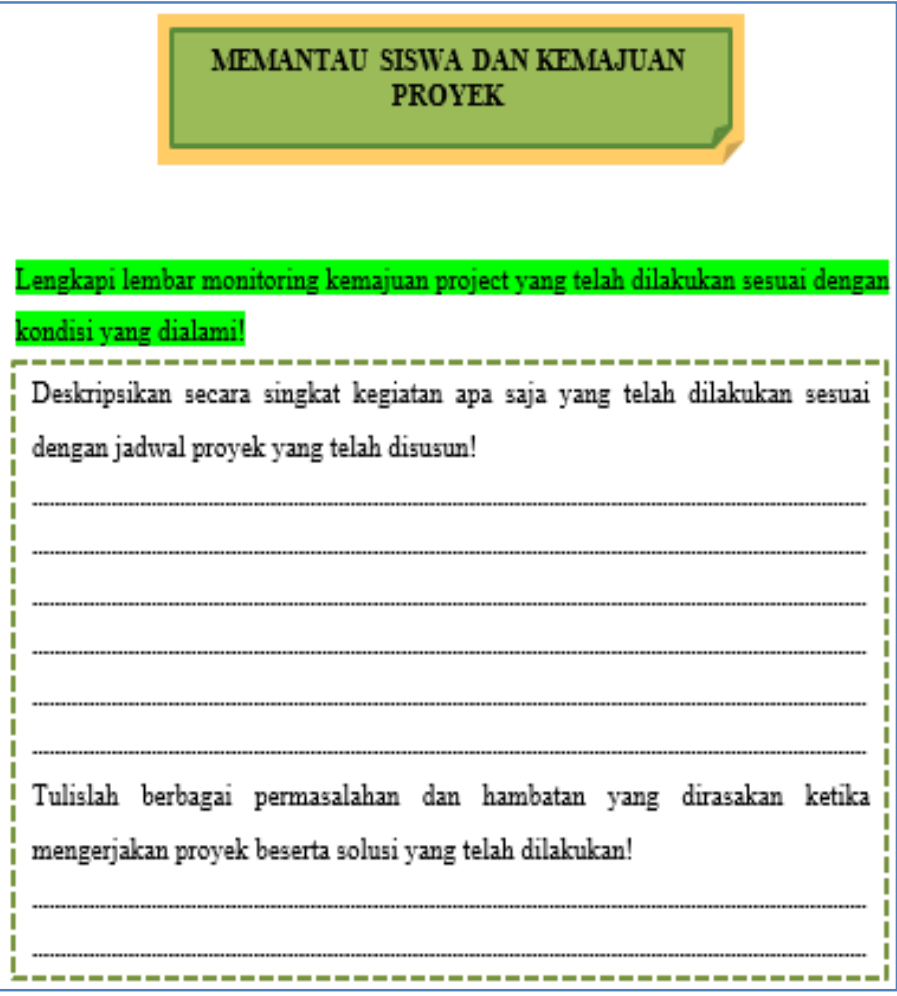

Gambar 7. Sintaks Memantau Siswa dan Kemajuan Proyek 


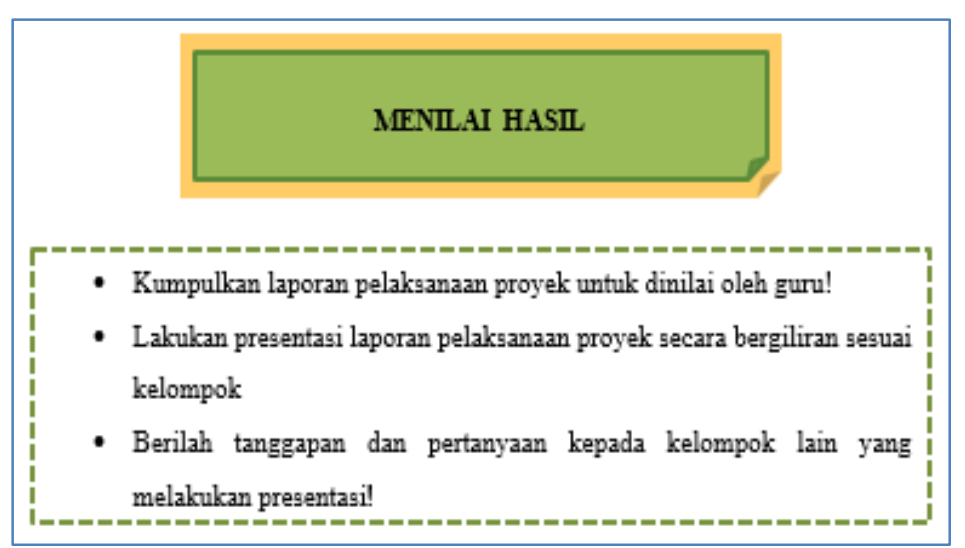

Gambar 8. Sintaks Menilai Hasil

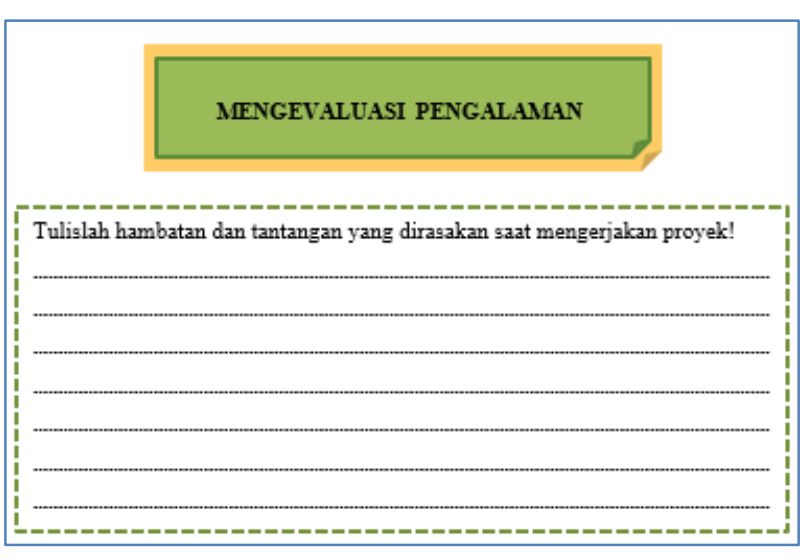

Gambar 9. Sintaks Mengevaluasi Pengalaman

Tabel 1. Hasil Analisis Validasi Modul oleh Ahli Materi

\begin{tabular}{clcccc}
\hline No & \multicolumn{1}{c}{ Aspek } & Skor/Skor Maks & Persentase & Kategori & Keputusan Uji \\
\hline 1 & Kesesuaian materi dengan KD & $12 / 12$ & $100 \%$ & Sangat valid & Sedikit revisi \\
2 & Keakuratan materi & $40 / 44$ & $90,90 \%$ & Sangat valid & Sedikit revisi \\
3 & Kedalaman materi & $8 / 8$ & $100 \%$ & Sangat valid & Sedikit revisi \\
4 & Kekontekstualan materi & $11 / 12$ & $91,66 \%$ & Sangat valid & Sedikit revisi \\
5 & Kemutakhiran materi & $11 / 12$ & $91,66 \%$ & Sangat valid & Sedikit revisi \\
6 & Mendorong keingintahuan & $12 / 12$ & $100 \%$ & Sangat valid & Sedikit revisi \\
7 & Penyajian materi & $18 / 20$ & $90 \%$ & Sangat valid & Sedikit revisi \\
\hline & Rerata total & & $\mathbf{9 4 , 8 8 \%}$ & Sangat valid & Sedikit revisi \\
\hline
\end{tabular}

Tabel 1 menunjukkan bahwa keseluruhan aspek validasi oleh ahli materi termasuk kategori sangat valid dengan keputusan sedikit revisi. Rata-rata persentase keseluruhan aspek validasi 94,88\% termasuk kategori sangat valid dengan keputusan uji sedikit revisi. Saran perbaikan yang diberikan oleh ahli materi yaitu, (1) gambar yang terdapat dalam modul disesuaikan dengan konteks seperti bentuk daun, (2) pemberian skala atau ukuran pada setiap gambar, (3) penggunaan istilah baku pada modul, (4) menghindari kesalahan ketik huruf maupun istilah, dan (5) ukuran gambar tidak terlalu kecil dengan kontras yang jelas.

\section{Validasi Oleh Ahli Modul}

Validasi oleh ahli modul meliputi lima aspek yaitu self instruction, self contained, stand alone, adaptif, user friendly. Ringkasan hasil analisis persentase validasi modul oleh ahli modul secara lengkap terdapat pada tabel 2.

Tabel 2. Hasil Analisis Validasi oleh Ahli Modul

\begin{tabular}{clcccc}
\hline No & Aspek & Skor/Skor Maks & Persentase & Kategori & Keputusan Uji \\
\hline 1 & Self instruction & $26 / 32$ & $81,25 \%$ & Cukup valid & Sedikit revisi \\
2 & Self contained & $7 / 8$ & $87,50 \%$ & Sangat valid & Sedikit revisi \\
3 & Stand alone & $10 / 12$ & $83,33 \%$ & Cukup valid & Sedikit revisi \\
4 & Adaptif & $12 / 12$ & $100 \%$ & Sangat valid & Sedikit revisi \\
5 & User friendly & $44 / 48$ & $91,66 \%$ & Sangat valid & Sedikit revisi \\
\hline & Rerata total & & $\mathbf{8 8 , 7 4 \%}$ & Sangat valid & Sedikit revisi \\
\hline
\end{tabular}

Tabel 2 menunjukkan bahwa lima aspek validasi oleh ahli modul termasuk kategori sangat valid dengan keputusan sedikit revisi. Rata-rata persentase keseluruhan aspek validasi oleh ahli modul adalah 88,74\% termasuk kategori sangat valid dengan keputusan sedikit revisi. Saran perbaikan yang diberikan oleh ahli modul yaitu, (1) font yang digunakan dalam modul untuk anak jenjang SMK sebaiknya bukan Comic Sun, tetapi Times New Roman atau Arial, (2) rumusan tujuan pembelajaran perlu direvisi pada ketiga kegiatan belajar, (3) langkah kerja pada LKS tidak belum berbentuk langkah kerja, (4) perlu ditambahkan kunci jawaban, dan (5) rubrik penilaian dibuat konsisten.

\section{Validasi Praktisi Lapangan}

Aspek validasi modul oleh praktisi lapangan merupakan gabungan aspek yang terdapat pada angket validasi yang dinilai oleh ahli materi dan ahli modul yang disesuaikan dengan tingkat kepraktisan di lapangan. Angket validasi oleh praktisi lapangan terdiri dari 32 butir. Ringkasan hasil analisis persentase validasi oleh praktisi lapangan secara lengkap terdapat pada tabel 3 . 
Tabel 3. Hasil Analisis Validasi Praktisi Lapangan

\begin{tabular}{cccccc}
\hline Jumlah Butir Validasi & Skor Maks & Skor Hasil Validasi & Persentase & Kategori & Keputusan Uji \\
\hline 32 & 128 & 123 & $96,09 \%$ & Sangat valid & Sedikit revisi \\
\hline
\end{tabular}

Tabel 3 menunjukkan persentase validasi modul oleh praktisi lapangan adalah 96,09\% dengan kategori sangat valid dan memerlukan sedikit revisi. Komentar yang diberikan oleh praktisi lapangan terhadap modul yang dikembangkan adalah tampilan modul secara umum sudah menarik serta bahasa yang digunakan mudah dipahami siswa SMK. Saran perbaikan yang diberikan memperbesar dan membuat menjadi detail beberapa gambar yang terdapat dalam modul.

\section{Uji Coba Pendahuluan}

Modul yang telah valid dan direvisi berdasarkan saran dari validator ahli materi, ahli modul dan praktisi lapangan diuji kepraktisan secara terbatas yang meliputi uji coba perseorangan dan uji coba kelompok kecil. Hasil uji coba perseorangan yang diikuti tiga siswa terdapat pada tabel 4.

Tabel 4. Hasil Uji Coba Perseorangan (3 Siswa)

\begin{tabular}{cccccc}
\hline Jumlah Butir Validasi & Skor Maks & Skor Hasil Validasi & Persentase & Kategori & Keputusan Uji \\
\hline 32 & 384 & 357 & $92,96 \%$ & Sangat Praktis & Sedikit revisi \\
\hline
\end{tabular}

Tabel 4 menunjukkan hasil uji coba perseorangan untuk tingkat kepraktisan memperoleh persentase rata-rata 92,96\% dengan kategori sangat praktis dengan keputusan memerlukan sedikit revisi. Saran yang diberikan siswa pada uji perseorangan meliputi perbaikan ukuran gambar menjadi lebih besar dan peningkatan kontras pada beberapa bagian gambar modul. Modul yang direvisi setelah uji coba perseorangan digunakan untuk uji kelompok kecil yang diikuti oleh enam siswa yang ditunjukkan pada tabel 5 .

Tabel 5. Hasil Uji Coba Kelompok Kecil (6 siswa)

\begin{tabular}{cccccc}
\hline Jumlah Butir Validasi & Skor Maks & Skor Hasil Validasi & Persentase & Kategori & Keputusan Uji \\
\hline 32 & 768 & 703 & $91,53 \%$ & Sangat Praktis & Sedikit revisi \\
\hline
\end{tabular}

Tabel 5 menunjukkan hasil uji coba kelompok kecil untuk tingkat kepraktisan memperoleh persentase rata-rata 91,53\% dengan kategori sangat praktis dengan keputusan memerlukan sedikit revisi. Saran yang diberikan siswa pada uji kelompok kecil adalah masih dijumpai gambar polong kedelai yang ukuran kecil sehingga perlu diperbesar agar lebih detail.

\section{Uji Coba Lapangan}

Modul yang direvisi setelah uji coba pendahuluan selanjutnya digunakan dalam uji coba lapangan. Tujuan uji coba lapangan adalah mengetahui tingkat kepraktisan dari modul yang dikembangkan. Siswa yang mengikuti uji coba lapangan adalah siswa kelas XI tanaman pangan dan hortikultura berjumlah 23 orang. Ringkasan uji coba lapangan terdapat pada tabel 6.

Tabel 6. Hasil Uji Coba Lapangan (23 siswa)

\begin{tabular}{cccccc}
\hline Jumlah Butir Validasi & Skor Maks & Skor Hasil Validasi & Persentase & Kategori & Keputusan Uji \\
\hline 32 & 2944 & 2751 & $93,44 \%$ & Sangat Praktis & Sedikit revisi \\
\hline
\end{tabular}

Tabel 6 menunjukkan persentase rata-rata tingkat keterbacaan pada uji coba lapangan adalah 93,44\% dengan kategori sangat praktis dan keputusan uji sedikit revisi. Komentar yang diberikan siswa saat uji coba lapangan adalah modul sudah dilengkapi dengan gambar ilustrasi yang menarik, bahasa yang digunakan mudah dipahami serta huruf dalam modul mudah untuk dibaca. Saran perbaikan yang diberikan siswa adalah memperjelas beberapa keterangan gambar pada modul, terutama yang berupa alur kegiatan agar lebih mudah dipahami.

\section{PEMBAHASAN}

Modul dipilih sebagai jenis bahan ajar untuk dikembangkan karena sesuai dengan permasalahan yang ditemui di lapangan. Hasil analisis kebutuhan didapatkan kondisi ketersediaan bahan ajar yang terbatas terutama yang membahas materi analisis karakter tanaman pangan spesifik seperti kedelai. Alokasi waktu yang tersedia tidak cukup untuk membahas secara detail berbagai karakteristik tanaman pangan yang berbeda. Pengembangan modul sesuai untuk mengatasi kondisi tersebut karena memiliki karakteristik sebagai bahan ajar yang dapat digunakan secara mandiri oleh siswa (Depdiknas, 2008). Ketuntasan belajar siswa juga bisa diketahui melalui soal evaluasi dan umpan balik yang tersedia pada modul (Santyasa, 2009). 
Kegiatan pembelajaran SMK lebih berorientasi pada kegiatan praktik dibandingkan dengan kegiatan pembelajaran tatap muka di kelas. Modul yang berbasis $P j B L$ dapat mendukung pembelajaran yang berbasis praktik karena memiliki sintaks yang memfasilitasi siswa untuk berpikir dan melakukan aktivitas fisik (Kwietniewski, 2017). Aktivitas yang dilakukan siswa berkaitan dengan pemecahan masalah autentik dan terdapat produk sebagai hasil proses belajar (Division, 2006; Woro, 2015). Modul yang telah selesai disusun sesuai rancangan pada tahap design selanjutnya di validasi pada tahap develop. Hasil validasi ahli materi berdasarkan tujuh aspek didapatkan nilai rata-rata 94,88\% sehingga modul dinyatakan sangat valid dan terdapat sedikit revisi. Aspek dengan nilai terkecil adalah penyajian materi dengan persentase $90 \%$. Hal yang perlu ditingkatkan dari modul melalui revisi adalah aspek penyajian materi yang memperhatikan prinsip dari hal umum ke hal khusus. Siswa lebih mudah memahami suatu materi bahan ajar bila penyajian dari umum ke khusus (Latifah, 2018). Bagian lain yang juga perlu direvisi dari modul adalah pemberian skala pada gambar, peningkatan ukuran dan kontras gambar serta perbaikan pemakaian istilah yang tidak tepat.

Hasil validasi ahli modul berdasarkan lima aspek penilaian didapatkan rata-rata nilai $88,74 \%$ dengan kriteria sangat valid dengan keputusan sedikit revisi. Aspek dengan nilai terkecil adalah self instruction, hal ini karena rubrik penilaian modul saat proses validasi tidak konsisten. Rubrik sangat penting terutama pada soal uraian. Rubrik yang tidak konsisten menyebabkan penilaian subjektif. Rubrik penilaian dikatakan konsisten bila terdapat kejelasan unsur nilai dengan degradasi angka yang konsisten (Yulyantari, 2017). Saran diberikan validator ahli modul adalah perubahan jenis huruf yang digunakan dalam modul sehingga lebih mudah dibaca dan sesuai digunakan untuk siswa SMK. Saran lainnya adalah perubahan konstruksi pembuatan tujuan pembelajaran juga disesuaikan dengan aktivitas pembelajaran yang dilakukan. Tujuan pembelajaran dibuat mempertimbangkan aspek siswa, perubahan tingkah laku yang diinginkan, kondisi untuk menciptakan perubahan dan ukuran level yang ingin dicapai (Kemendikbud, 2017a).

Validasi oleh praktisi lapangan mendapatkan rata-rata nilai 96,09\% dengan kriteria sangat valid dan keputusan uji memerlukan sedikit revisi. Secara umum, validator memberikan komentar modul telah disusun dengan menggunakan bahasa yang mudah dipahami serta ilustrasi gambar yang diberikan memperjelas penyajian materi. Saran perbaikan yang diberikan adalah memperbesar dan memperjelas tampilan bentuk objek gambar, seperti biji kedelai hasil persilangan. Modul yang telah dinyatakan valid dan direvisi sesuai saran validator selanjutnya digunakan dalam uji pendahuluan. Uji kelompok kecil melibatkan tiga siswa yang telah memperoleh materi untuk menilai kepraktisan modul. Nilai rata-rata uji perseorangan adalah 92,96\% dengan kriteria sangat praktis dan memerlukan sedikit revisi yaitu peningkatan kecerahan gambar pada struktur pengamatan anatomi daun yang meliputi gambar stomata dan trikoma. Uji kelompok kecil melibatkan enam siswa dengan rata-rata nilai hasil uji kepraktisan 91,53\% sehingga modul dikategorikan sangat praktis dan memerlukan sedikit revisi. Revisi uji kelompok kecil adalah perbaikan gambar polong kedelai yang kurang jelas sehingga objek gambar dipotong dan diperbesar. Modul yang telah direvisi digunakan dalam uji coba lapangan di kelas XI. Hasil uji mendapatkan rata-rata nilai 93,44\% dengan kriteria sangat praktis dan memerlukan sedikit revisi. Perbaikan pada keterangan gambar yang menunjukkan suatu proses dibuat lebih sederhana dengan diagram alir.

Secara keseluruhan, modul sudah dinyatakan sangat valid dan praktis sehingga dapat digunakan sebagai bahan ajar. Keunggulan modul yang dikembangkan adalah ilustrasi gambar dan data-data yang disajikan bersumber hasil penelitian sehingga lebih bersifat kontekstual. Kelemahan modul yang dikembangkan adalah perlu diuji lebih lanjut efektivitas dalam proses pembelajaran di sekolah tempat analisis kebutuhan dilakukan maupun sekolah lain.

\section{SIMPULAN}

Modul analisis karakter morfologi, anatomi dan agronomi berbasis $P j B L$ yang dikembangkan berdasarkan hasil penelitian dinilai valid oleh ahli materi, ahli modul dan praktisi lapangan sehingga dapat digunakan dalam kegiatan pembelajaran. Perlu penelitian lebih lanjut tentang uji efektivitas modul yang telah dikembangkan pada SMK pertanian tempat analisis kebutuhan dilakukan maupun sekolah lain.

\section{DAFTAR RUJUKAN}

Aisyah, N. (2011). Peningkatan Hasil Belajar Mahasiswa Menggunakan Modul. Jurnal Ilmu Pendidikan, 17(5), 393-400.

Akbar, S. (2013). Instrumen Perangkat Pembelajaran. Bandung: Remaja Rosdakarya.

Akhiruddin., Susilo, H., \& Ibrohim. (2016). Pengaruh Penggunaan Modul Inkuiri Dipadu PjBL Berbahan Ajar Potensi Lokal terhadap Keterampilan Proses Sains Siswa SMA. Jurnal Pendidikan: Teori, Penelitian, dan Pengembangan, 1(10), 1964-1968.

Apri, S., \& Marwoto. (2011). Hubungan antara Trikoma dan Intensitas Kerusakan Daun dengan Ketahanan Kedelai terhadap Hama Kutu Kebul (Bemisia tabaci). In Seminar Nasional Hasil Penelitian Tanaman Aneka Kacang dan Umbi Balitkabi. Malang.

Baker, E., Trygg, B., Otto, P., Tudor, M., \& Ferguson, L. (2011). Project-Based Learning Model Relevant Learning Relevant Learning for the 21 st Century Project-based Learning Model. Columbia: Pacific Education Institute.

Branch, R. M. (2009). Instructional Design: The ADDIE Approach. New York: Springer Science + Bussines Media, LLC.

Division, E. T. (2006). Project-Based Learning Handbook “Educating the Millennial Learner.” Kuala Lumpur: Communications and Training Sector Smart Educational Development Educational Technology Division Ministry of Education. 
Faot, M. M., Zubaidah, S., \& Kuswantoro, H. (2016). Pengembangan Modul Teknik Budidaya Tanaman Kedelai sebagai Bahan Ajar Sekolah Menengah Kejuruan. Jurnal Pendidikan: Teori, Penelitian, dan Pengembangan, 1(7), 1421-1426.

Hanafi, I. (2012). Re-Orientasi Keterampilan Kerja Lulusan Pendidikan Kejuruan. Jurnal Pendidikan Vokasi, 2(1), $107-116$. https://doi.org/10.21831/jpv.v2i1.1021

Kemendikbud. (2017a). Analisis Materi Pelajaran. Jakarta: Direktorat Pendidikan Sekolah Menengah Kejuruan.

Kemendikbud. (2017b). Pedoman Penyelenggaraan Uji Kompetensi Keahlian Tahun Pelajaran 2016/2017. Jakarta: Kementerian Pendidikan dan Kebudayaan. Jakarta: Direktorat Pendidikan Sekolah Menengah Kejuruan.

Kwietniewski, K. (2017). Literature Review of Project Based Learning. State University of New York.

Latifah, L. (2018). Analisis Kelayakan Penyajian Buku Teks Bahasa Indonesia Ekspresi Diri dan Akademik SMA/SMK Kelas X Edisi Revisi 2014. Universitas Muhammadiyah Surakarta.

Nurrohman, E., Zubaidah, S., \& Kuswantoro, H. (2012). Pengembangan Modul Pembelajaran IPA. Jurnal Pendidikan: Teori, Penelitian, dan Pengembangan, 2(7), 1003-1007.

Paulina Dewi, R., Rohman, F., \& Zubaidah, S. (2016). Hubungan Preferensi Bemisia Tabaci terhadap Ketahanan Berbagai Galur Harapan Dan Varietas Kedelai (Glycine Max L. Merill) Tahan CPMMV (Cowpea Mild Mottle Virus) sebagai Bahan Ajar Pengendalian Hama Tanaman. Jurnal Pendidikan: Teori, Penelitian, dan Pengembangan, 1517-1522.

Pusdatin. (2016). Outlook Komoditas Pertanian Tanaman Pangan Kedelai. Jakarta.

Sa'diyah, N., Akin, H. M., Putri, R., Jamil, R., \& Barmawi, M. (2017). Heritabilitas, Nisbah Potensi, dan Heterosis Ketahanan Kedelai (Glycine max [L.] Merrill) terhadap Soybean Mosaic Virus. Jurnal Hama dan Penyakit Tumbuhan Tropika, 16(1), 17-24. https://doi.org/10.23960/j.hptt.11617-24

Safitri, N. L., Zubaidah, S., \& Kuswantoro, H. (2018). Pengembangan LKS Project Based Learning Berbasis Penelitian Perlakuan Perbedaan Dosis Fosfat pada Genotipe Kedelai. Jurnal Pendidikan: Teori, Penelitian, dan Pengembangan, $3(4), 518-523$.

Samsudi. (2014). Pengembangan Model Pembelajaran Program Produktif SMK untuk Membentuk Karakter Kewirausahaan Lulusan. Jurnal Cakrawala Pendidikan, 2(2), 307-314.

Santyasa, I. W. (2009). Metode Penelitian Pengembangan dan Teori Pengembangan Modul. In Pelatihan Bagi Guru TK, SD, SMP, SMA, dan SMK di Kecamatan Nusa Penida Kabupaten Klungkung.

Setiawan, T. A., Zubaidah, S., \& Kuswantoro, H. (2016). Morfologi Galur-Galur Harapan Kedelai Tahan CPMMV (Cowpea Mild Mottle Virus) sebagai Sumber Belajar Biologi. Bioedukasi Jurnal Pendidikan Biologi, 7(1), 363-368.

Suhartono, R., \& Soeharto. (2014). Upaya Peningkatan Kualitas Pembelajaran Membubut Mata Pelajaran Kerja Mesin Lanjut menggunakan Model Praktik Berpasangan. Jurnal Pendidikan Vokasi, 4(1), 57-66. https://doi.org/10.21831/jpv.v4i1.2535

Sutrisno, V. L. P., \& Siswanto, B. T. (2016). The Teaching and Learning of Automotive Electrical. Jurnal Pendidikan Vokasi, $6(1), 112-120$.

Swandhana, K. (2016). Meningkatkan Kemandirian Belajar dan Hasil Belajar Siswa melalui Pengembangan Modul Administrasi Kepegawaian Berbasis Strategi Pembelajaran Inkuiri Terbimbing. Jurnal Pendidikan Bisnis dan Manajemen, 2(3), 161-169.

Tahlim, S., \& Swastika, D. K. (2013). Ekonomi Kedelai di Indonesia. In Kedelai Teknik Produksi dan Pengembangan (pp. 127).

Wardhani, D. K., Zubaidah, S., \& Kuswantoro, H. (2017). Uji Kelayakan Perangkat Pembelajaran Berbasis Penelitian Pengaruh Konsentrasi Giberelin terhadap Keragaan Galur-Galur Kedelai Tahan CpMMV. Jurnal Pendidikan: Teori, Penelitian, dan Pengembangan, 2(12), 1596-1602.

Wijaya, I., Zubaidah, S., \& Kuswantor, H. (2016). Anatomi Daun Galur-Galur Harapan Kedelai (Glycine Max L. Merill) Tahan CPMMV (Cowpea Mild Mottle Virus) sebagai Sumber Belajar. Jurnal Pendidikan, 1(3), 463-467.

Windriyas, W. N. (2014). Analisis Pencapaian Kompetensi Peserta Didik SMK Kelas X Diklat Keahlian Bisnis dan Manajemen dalam Pengembangan Kurikulum 2013 di SMK Widya Praja Ungaran. Economic Education Analysis Journal, 3(3), 594602.

Woro, S. (2015). The Strengths and Weakness of the Implementation of Project Based Learning. International Jornal of Science and Research (IJSR), 4(3), 478-484.

Yulyantari, L. M. (2017). Penilaian Essai Menggunakan Rubrik Penilaian. In Konferensi Nasional Sistem \& Informatika STMIK STIKOM (pp. 368-372). Denpasar: STIKOM Bali.

Zubaidah, S. (2018). Keterampilan Abad Ke-21: Bagaimana Membelajarkan dan Mengaksesnya. In Tantangan Biologi dan Pendidikan Biologi Abad-21. Riau: Pendidikan Biologi FKIP Universitas Islam Riau.

Zubaidah, S., \& Kuswantoro, H. (2017). Foliar Symptoms Recovery: Developing Scoring Technique for Assessment of Soybean Resistance to CPMMV (Cowpea Mild Mottle Virus). Journal of Biological Researches, 21(2), 85-89. https://doi.org/10.23869/bphjbr.21.2.20167 